\title{
PENGARUH PEMBIAYAAN PRODUKTIF DAN KONSUMTIF PERBANKAN SYARIAH TERHADAP PERTUMBUHAN EKOMONI DI INDONESIA PERIODE 2013-2017
}

\author{
Anton Sudrajat \\ antonsudrajat83@gmail.com \\ Fakultas Syariah IAIN Ponorogo \\ Amirus Sodiq \\ sodiqamirus@gmail.com \\ STAIN Kudus
}

\begin{abstract}
In order for a country's economy to grow needed economic resources one of which is the capital that comes from banking. The capital is used for production purposes so that it can increase productivity and in turn can cause economic growth of a country. The purpose of this study is to determine the effect of productive financing and consumptive financing of sharia banking to economic growth in Indonesia. The results showed that partially productive financing of sharia banking has a significant effect on economic growth in Indonesia. While consumptive financing of sharia banking has no significant effect on economic growth in Indonesia. Simultaneously, productive and consumer financing of sharia banking has a significant effect on economic growth in Indonesia with $91.3 \%$ influence.
\end{abstract}

Keywords: Financing, Productive, Consumptive, Econonomic Growth, GDP.

\section{A. Pendahuluan}

Fenomena maraknya gelombang aktivitas implementasi nilainilai Islam dalam bidang ekonomi yang hampir merata di seluruh negara muslim bahkan di negara-negara non muslim menunjukkan bukan hanya sekedar perubahan etika moral individu, melainkan keseluruhan sistem ekonomi dan dianggap sebagai "jalan ketiga" 
di antara kapitalisme dan sosialisme di saat masyarakat global mencari keselarasan sistem ekonomi yang efesien dan humanis akibat kenyataan sistem kapitalis pasar yang menghadirkan banyak masalah ekonomi yang melangsungkan malapetaka bagi perekonomian dunia. (Rosser dan Marina, 2004: 3)

Usaha-usaha untuk mendirikan bank Islam menemukan memontumnya terutama di negara-negara yang mayoritas penduduknya muslim. Pada tahun 1979, Pakistan merupakan negara pertama yang mengaplikasikan program islamisasi total dalam sistem ekonomi dan keuangannya (Warde, 2009: 238). Negara Iran memperkenalkan islamisasi sektor perbankan dimulai pada bulan Maret 1984 (Chapra, 2001: 285). Di Sudan, tepatnya pada Desember 1985 semua bank yang beroperasi mengikuti prinsip Islam dalam aktivitasnya (Muhammad, 2002: 170). Pada Tahun 1993, Warde (2009: 269) juga menyebutkan bahwa Malaysia mengambil langkah sebagai pelopor yang memperkenalkan sistem perbankan ganda (dual-banking system). Sedangkan di Indonesia melalui pengesahan UU No. 7 Tahun 1992 yang meletakkan dasar bagi eksistensi bank Islam di Indonesia dan melegitimasi sistem perbankan syariah sebagai salah satu sistem perbankan yang berlaku di Indonesia (Kara, 2005: 186).

Perkembangan bank syariah di Indonesia diperkuat dengan diundangkannya UU No. 10 tahun 1998 yang memungkinkan bagi bank umum dengan sistem konvensional dapat membuka kantor cabang atau kantor di bawah kantor cabang dengan prinsip konvensional dan syariah (double window), dan juga memungkinkan bank umum dengan sistem konvensional dapat merubah kantor cabang atau kantor di bawah kantor cabang konvensional menjadi sistem syariah (Kara, 2005: 202). Dalam implementasinya, menurut Farouk \& Umam (2009: 2) terdapat kecenderungan melakukan pemisahan (spin-off) Unit Usaha Syariah (UUS) dari kantor pusat suatu bank konvensional dan dijadikan Bank Umum Syariah (BUS) tersendiri.

Keseriusan pemerintah melalui pembentukan peraturan perundang-undangan oleh regulator berdampak pada perluasan jaringan kantor, pengembangan pasar uang antarbank syariah, peningkatan kualitas sumber daya manusia, dan peningkatan 
kinerja bank syariah di Indonesia (Kara, 2005: 203). Selain itu, kinerja perbankan syariah juga terus mengalami peningkatan. Hal ini bisa dilihat dalam kinerja perbankan syariah tahun 2013 melalui tabel berikut: (BI, 2014)

Tabel 1.

Kinerja Perbankan Syariah PerOktober 2013

\begin{tabular}{|c|c|}
\hline VARIABEL & INDIKATOR \\
\hline Intermediasi & $\begin{array}{l}\text { Financing to Deposit Ratio (FDR) mencapai } 103,0 \% \\
\text { Pembiayaan Yang Diberikan (PYD) tumbuh relatif tinggi } \\
32,2 \% \text { yoy }\end{array}$ \\
\hline Ketahanan & $\begin{array}{l}\text { Capital Adequacy Ratio (CAR) mencapai 14,19\% } \\
\text { Non Performing Financing (NPF) mencapai 2,96\% }\end{array}$ \\
\hline Penetrasi & $\begin{array}{l}\text { Deposit Account } 12,3 \text { juta }( \pm 9,2 \% \text { nasional) } \\
\text { Dengan jumlah } 11 \text { BUS, } 23 \text { UUS, dan } 160 \text { BPRS dengan } \\
\text { jumlah jaringan kantor } 2526(+14,1 \% \text { nasional })\end{array}$ \\
\hline
\end{tabular}

Sumber: Outlook Perbankan Syariah 2014

Selain pencapaian kinerja yang baik, perbankan syariah juga mengalami peningkatan dari segi jumlah bank yang beroperasi di Indonesia. Berdasarkan data statistik perbankan syariah dari tahun 2008 sampai bulan September 2014, jumlah bank yang melakukan kegiatan usaha syariah pada tahun 2014 mencapai 197 bank yang terdiri dari 11 Bank Umum Syariah (BUS) dan 23 Unit Usaha Syariah (UUS) serta 163 Bank Pembiayaan Rakyat Syariah (BPRS). (OJK, 2014)

\section{Tabel 2.}

Perkembangan Bank Syariah di Indonesia

\begin{tabular}{cccccccc}
\hline Jenis Bank & $\mathbf{2 0 0 8}$ & $\mathbf{2 0 0 9}$ & $\mathbf{2 0 1 0}$ & $\mathbf{2 0 1 1}$ & $\mathbf{2 0 1 2}$ & $\mathbf{2 0 1 3}$ & $\mathbf{2 0 1 4}$ \\
\hline Bank Umum Syariah & 5 & 6 & 11 & 11 & 11 & 11 & 11 \\
\hline Unit Usaha Syariah & 27 & 25 & 23 & 24 & 24 & 23 & 23 \\
\hline $\begin{array}{c}\text { Bank Pembiayaan } \\
\text { Rakyat Syariah }\end{array}$ & 131 & 138 & 150 & 155 & 158 & 163 & 163 \\
\hline Total & 163 & 169 & 184 & 190 & 193 & 197 & 197 \\
\hline
\end{tabular}

Sumber: Statistik Perbankan Syariah, September 2014

Peningkatan jumlah bank syariah di Indonesia tentunya akan berdampak pada penyaluran pembiayaan melalui produk dan jasa perbankan syariah yang semakin kompleks dan beragam, seperti pembiyaan produktif dan pembiayaan konsumtif sehingga dapat memberikan kontribusi pada pertumbuhan ekonomi di Indonesia 
terutama sektor riil. Pembiayaan yang disalurkan oleh perbankan syariah berperan penting untuk membiayai kegiatan perekonomian untuk menopang pertumbuhan ekonomi Indonesia. Sebagai contoh pembiayaan produktif perbankan syariah biasanya digunakan oleh dunia usaha untuk kepentingan produksi seperti membangun pabrik-pabrik dan mesin-mesin baru atau membeli bahan mentah sebagai bahan baku untuk kepentingan proses produksi yang dapat menghasilkan barang dan jasa. Sedangkan pembiayaan konsumtif perbankan syariah biasanya digunakan untuk oleh masyarakat untuk memenuhi kebutuhan konsumsi seperti pembelian kendaraan, perumahan, dll. Pembiayaan produktif berdampak pada produktivitas sektor usaha sedangkan pembiayaan konsumtif berdampak pada peningkatan daya beli masyarakat dimana kedua hal tersebut berkontribusi pada pertumbuhan ekonomi suatu negara.

Berdasarkan latar belakang masalah ini, maka rumusan masalah dalam penelitian ini adalah: 1) Apakah pembiayaan produktif perbankan syariah secara parsial berpengaruh signifikan terhadap Pertumbuhan ekonomi di Indonesia periode 2013-2017 ? 2) Apakah pembiayaan konsumtif perbankan syariah secara parsial berpengaruh signifikan terhadap Pertumbuhan ekonomi di Indonesia periode 2013-2017 ? 3) Apakah pembiayaan produktif dan pembiayaan konsumtif perbankan syariah secara simultan berpengaruh signifikan terhadap Pertumbuhan ekonomi di Indonesia periode 2013-2017?

\section{B. Kajian Pustaka}

Penelitian tentang pengaruh pembiayaan perbankan syariah terhadap pertumbuhan ekonomi di Indonesia belum banyak dilakukan. Namun, ada beberapa penelitian yang sejenis, seperti studi yang dilakukan oleh Anthony (2010) yang menganalisis pengaruh kredit pertanian terhadap pertumbuhan ekonomi di Negeria. Hasil penelitian ini menunjukkan bahwa kredit pertanian berpengaruh positif signifikan terhadap pertumbuhan kredit di Nigeria.

Penelitian Fithriyah \& Malik (2010) menganalisis pengaruh kredit perbankan terhadap pertumbuhan industri manufaktur dalam 
menunjang pertumbuhan ekonomi Indonesia. Hasil penelitian ini menunjukkan bahwa kredit perbankan berpengaruh positif signifikan terhadap pertumbuhan ekonomi Indonesia. Sedangkan penelitian yang dilakukan oleh Departemen Pengembangan Pengawasan dan Manajemen Krisis Divisi Analisis Profil Industri Otoritas Jasa Keuangan (2015) tentang potensi pertumbuhan ekonomi ditinjau dari penyaluran kredit perbankan kepada sektor prioritas. Hasil penelitian ini mendapatkan temuan bahwa saat terjadi hubungan positif antara kredit dan pertumbuhan ekonomi, maka terlihat bahwa kredit kepada 5 sektor prioritas (pertanian, perikanan, konstruksi, pertambangan dan industri pengolahan) memberikan sumbangan informasi yang relatif signifikan terhadap perubahan pertumbuhan ekonomi, baik perubahan yang sifatnya naik atau turun.

\section{Landasan Teori}

Pertumbuhan ekonomi adalah sangat penting dalam pembangunan suatu negara. Karena indikator keberhasilan pembangunan suatu negara dapat diukur dengan kenaikan pertumbuhan ekonomi dari masa ke masa. Pertumbuhan ekonomi berperan dalam memperbesar skala ekonomi suatu negara yang berdampak pada meluasnya aktivitas ekonomi pada semua sektor usaha. Dengan kata lain peluang kesempatan kerja akan terus bertambah dari masa ke masa yang dapat menurunkan tingkat pengangguran. Selain itu, pertumbuhan ekonomi berperan dalam meningkatkan pendapatan masyarakat. Hal ini terjadi karena terjadinya pertambahan produktivitas semua sektor usaha. Agar perekonomian suatu negara dapat tumbuh diperlukan sumbersumber ekonomi salah satunya adalah modal (Nain dan Yusoff, 2003: 21). Modal untuk kepentingan dunia usaha dapat bersumber dari perbankan. Modal tersebut digunakan untuk keperluan produksi sehingga dapat meningkatkan produktivitas dan pada gilirannnya dapat menyebabkan pertumbuhan ekonomi suatu negara. Menurut Levine \& Zervos (1998) perkembangan finansial yang digerakkan oleh perbankan melalui penyaluran kredit dapat meningkatkan akumulasi modal dan produktivitas sektor usaha 
yang pada gilirannya dapat menciptakan pertumbuhan ekonomi suatu negara.

Berdasarkan tinjauan pustaka dan landasan teori di atas dapat dikembangkan hipotesis sebagai berikut:

$\mathrm{H}_{\mathrm{o} 1}$ : Pembiayaan produktif perbankan syariah secara parsial tidak berpengaruh signifikan terhadap Pertumbuhan ekonomi di Indonesia

$\mathrm{H}_{\mathrm{a} 1}$ : Pembiayaan produktif perbankan syariah secara parsial berpengaruh signifikan terhadap Pertumbuhan ekonomi di Indonesia

$\mathrm{H}_{\mathrm{o} 2}$ : Pembiayaan konsumtif perbankan syariah secara parsial tidak berpengaruh signifikan terhadap Pertumbuhan ekonomi di Indonesia

$\mathrm{H}_{\mathrm{a} 2}$ : Pembiayaan konsumtif perbankan syariah secara parsial berpengaruh signifikan terhadap Pertumbuhan ekonomi di Indonesia

$\mathrm{H}_{\mathrm{o} 3}$ : Pembiayaan produktif dan konsumtif perbankan syariah secara simultan tidak berpengaruh signifikan terhadap Pertumbuhan ekonomi di Indonesia

$\mathrm{H}_{\mathrm{a} 3}$ : Pembiayaan produktif dan konsumtif perbankan syariah secara simultan berpengaruh signifikan terhadap Pertumbuhan ekonomi di Indonesia

Untuk membuktikan kebenaran dari hipotesis di atas, maka diperlukan analisis data. Untuk mengetahui pengaruh dari satu variabel independen terhadap variabel dependen peneliti menggunakan analisis regesi linier ganda dengan metode kuadrat terkecil atau Ordinary Least Square (OLS) dengan bantuan software Eviews 4.1

Adapun formulasi analisis regresi linear ganda dalam penelitian ini sebagai berikut:

$$
Y_{i t}=a+b_{1} X_{1 i t}+b_{2} X_{2 i t}+e_{i t}
$$

Keterangan:

$\mathrm{Y}=$ Pertumbuhan Ekonomi (PDB)

a $\quad=$ Konstanta

$\mathrm{b} \quad=$ Koefisien regresi

$\mathrm{X}_{1}=$ Pembiayaan Produktif 
$\mathrm{X}_{2} \quad=$ Pembiayaan Konsumtif

ei = Kesalahan pengganggu, berupa variabel atau faktor lain yang tidak diamati oleh model.

\section{Definisi Operasional Variabel Penelitian}

\section{Pertumbuhan Ekonomi}

Pertumbuhan ekonomi adalah peningkatan total output suatu perekonomian. Ekonomi tumbuh dikatakan mengalami pertumbuhan jika perekonomian memproduksi lebih banyak daripada yang diinginkan oleh masyarakat. Hal ini terjadi karena output tumbuh lebih cepat daripada jumlah penduduk, sehingga output per kapita meningkat dan standar kehidupan terangkat. Pertumbuhan ekonomi menunjukkan sejauhmana aktivitas perekonomian menghasilkan tambahan pendapatan masyarakat pada periode tertentu. Indikator yang digunakan untuk mengetahui pertumbuhan ekonomi suatu negara adalah Produk Domestik Bruto (PDB), karena: 1) PDB dihitung berdasarkan jumlah nilai tambah (value added) yang dihasilkan seluruh aktivitas produksi di dalam perekonomian, 2) PDB dihitung mencakup nilai produk yang dihasilkan pada suatu periode tertentu, 3) Batas wilayah perhitungan PDB adalah negara (perekonomian domestik). (Case and Fair, 2006: 19)

PDB yang digunakan dalam penelitian ini adalah PDB riil atas harga konstan tahun 2010 sebagai tahun basis untuk menilai barang dan jasa dalam perekonomian negara Indonesia periode 2013-2017. Karena PDB riil tidak dipengaruhi oleh perubahan harga, perubahan PDB riil hanya mencerminkan perubahan jumlah yang diproduksi. PDB riil mencerminkan kemampuan perekonomian untuk memenuhi kebutuhan dan hasrat orang sehingga PDB riil menjadi ukuran kesehatan ekonomi yang lebih baik daripada PDB nominal.(Mankiw, 2012:14)

\section{Pembiayaan Produktif}

Kredit produktif adalah kredit yang diberikan dengan tujuan untuk memperlancar jalannya proses produksi. (Suyatno, 2007: 25) Misalnya kredit yang digunakan untuk pembelian mesin-mesin usaha. Pembiayaan produktif dalam penelitian ini adalah jumlah 
dari pembiayaan untuk kepentingan investasi dan pembiayaan untuk kebutuhan modal kerja yang disalurkan oleh perbankan syariah kepada nasabahnya.

\section{Pembiayaan Konsumtif}

Kredit konsumtif adalah kredit yang diberikan dengan tujuan untuk memperlancar jalannya proses konsumsi (Suyatno, 2007: 25), seperti kredit kepemilik rumah (KPR), Kredit Pembelian motor, Credit Card, dan kredit lainnya (Judiseno, 2002: 170). Pembiayaan konsumtif dalam penelitian ini adalah pembiayaan yang disalurkan oleh perbankan syariah untuk memenuhi kebutuhan konsumsi nasabahnya seperti membeli kebutuhan rumah tangga, kendaraan, dan perumahan.

\section{E. Data}

Data yang digunakan dalam penelitian ini adalah data sekunder dari pembiayaan produktif dan pembiayaan konsumtif yang diperoleh dari Statistik Perbankan Syariah yang diterbitkan oleh Otoritas Jasa Keuangan dan Produk Domestik Bruto Negara Indonesia dengan periode observasi antara bulan April 2013 - Juni 2017 dengan ringkasan sebagai berikut:

\section{Tabel 3.}

Statistik Deskriptif Produk Domestik Bruto Negara Indonesia dan Pembiayaan Produktif dan Pembiayaan Konsumtif Perbankan Syariah di Indonesia periode April 2013 - Juni 2017

\begin{tabular}{lccc}
\hline & PDB & PRODUKTIF & KONSUMTIF \\
\hline Mean & 2.231 .698 & 122397.9 & 84169.69 \\
\hline Maximum & 2.472 .722 & 156389.0 & 109812.0 \\
\hline Minimum & 2.013 .598 & 89110.00 & 74296.00 \\
\hline
\end{tabular}

Sumber: Data Sekunder Diolah, 2017

\section{Pertumbuhan ekonomi}

Pertumbuhan ekonomi dalam penelitian ini diproksikan dengan Pendapatan Domestik Produk (PDB) Indonesia triwulanan atas dasar harga konstan tahun 2010. Berdasarkan tabel 1 menunjukkan bahwa rata-rata Pendapatan Domestik Produk (PDB) Indonesia sepanjang periode April 2013 - Juni 2017 adalah sebesar 
Rp 2.231 triliun. Pendapatan Domestik Produk (PDB) Indonesia tertinggi sebesar Rp 2.472 triliun terjadi pada triwulan II tahun 2017. Sedangkan Pendapatan Domestik Produk (PDB) Indonesia terendah Rp 2.013 triliun terjadi pada triwulan III tahun 2013.

\section{Pembiayaan produktif}

Pembiayaan produktif dalam penelitian ini adalah jumlah dari pembiayaan investasi dan pembiayaan modal kerja perbankan syariah. Berdasarkan tabel 1 menunjukkan bahwa rata-rata pembiayaan produktif Perbankan syariah sepanjang periode April 2013 - Juni 2017 adalah sebesar Rp 122 triliun. Pembiayaan produktif perbankan syariah tertinggi sebesar Rp 156 triliun terjadi pada bulan Juni tahun 2017. Sedangkan pembiayaan produktif perbankan syariah terendah Rp 89 triliun terjadi pada bulan April tahun 2014.

\section{Pembiayaan konsumtif}

Pembiayaan konsumtif dalam penelitian ini adalah pembiayaan yang disalurkan oleh perbankan syariah untuk memenuhi kepentingan konsumsi nasabah, seperti: kendaraan, rumah, dll. Berdasarkan tabel 1 menunjukkan bahwa rata-rata pembiayaan konsumtif Perbankan syariah sepanjang periode April 2013 - Juni 2017 adalah sebesar Rp 84 triliun. Pembiayaan konsumtif perbankan syariah tertinggi sebesar Rp 109 triliun terjadi pada bulan Juni tahun 2017. Sedangkan pembiayaan konsumtif perbankan syariah terendah Rp 74 triliun terjadi pada bulan April tahun 2014.

\section{F. Hasil Empiris}

Untuk melihat pengaruh variabel-variabel independen: Pembiayaan Produktif dan Pembiayaan Konsumtif terhadap variabel dependen Pertumbuhan Ekonomi di Indonesia dalam penelitian ini menggunakan bantuan software Eviews 4.1 diperoleh hasil estimasi sebagai berikut: 
Tabel 4.

Output Regresi

Dependent Variable: PDB

Method: Least Squares

Date: 11/12/17 Time: 09:53

Sample: 2013:04 2017:06

Included observations: 51

\begin{tabular}{llcll}
\hline Variable & Coefficient & Std. Error & t-Statistic & Prob. \\
\hline C & 408704.6 & 17308.82 & 23.61250 & 0.0000 \\
PRODUKTIF & 2.708544 & 0.206488 & 13.11719 & 0.0000 \\
KONSUMTIF & 0.043658 & 0.355883 & 0.122675 & 0.9029 \\
\hline \hline R-squared & 0.917090 & $\begin{array}{c}\text { Mean dependent } \\
\text { var }\end{array}$ & 743899.3 & \\
Adjusted R-squared & 0.913635 & $\begin{array}{c}\text { S.D. dependent } \\
\text { var }\end{array}$ & 47329.03 & \\
S.E. of regression & 13908.98 & $\begin{array}{c}\text { Akaike info } \\
\text { criterion }\end{array}$ & 21.97548 & \\
Sum squared resid & $9.29 \mathrm{E}+09$ & $\begin{array}{c}\text { Schwarz criterion } \\
\text { Log likelihood }\end{array}$ & -557.3747 & F-statistic \\
Durbin-Watson stat & 0.390715 & Prob (F-statistic) & 0.0000000 & \\
\hline
\end{tabular}

\section{Analisis Regresi}

Dari hasil tabel analisis regresi di atas dapat disusun persamaan regresi linear berganda sebagai berikut :

$$
\begin{gathered}
Y=a+b 1 X 1+b 2 X 2+b 3 X 3+e \\
Y=408.704,6+2,708 X 1+0,043 X 2
\end{gathered}
$$

Berdasarkan persamaan regresi tersebut dapat diinterpretasikan sebagai berikut:

a. Konstanta sebesar 408.704,6; artinya jika pembiayaan produktif dan pembiayaan konsumtif perbankan syariah adalah 0, maka Pertumbuhan Ekonomi Indonesia adalah sebesar Rp 408.704 triliun dengan asumsi faktor-faktor lain dianggap tetap (ceteris paribus).

b. Koefisien regresi pembiayaan produktif sebesar 2,708; artinya jika variabel independen lain nilainya tetap, sedangkan pembiayaan produktif perbankan syariah mengalami peningkatan sebesar 1\%, maka Pertumbuhan Ekonomi di Indonesia akan mengalami peningkatan sebesar 2,708 atau 270,8\%. Koefisien bernilai positif artinya 
terjadi hubungan searah antara pembiayaan produktif perbankan syariah dengan pertumbuhan ekonomi, semakin besar perbankan syariah menyalurkan pembiayaan produktif maka Pertumbuhan Ekonomi di Indonesia akan mengalami peningkatan.

c. Koefisien regresi pembiayaan konsumtif sebesar 0,043; artinya jika variabel independen lain nilainya tetap, sedangkan pembiayaan konsumtif perbankan syariah mengalami peningkatan sebesar $1 \%$, maka Pertumbuhan Ekonomi di Indonesia akan mengalami peningkatan sebesar 0,043 atau 4,3\%. Koefisien bernilai positif artinya terjadi hubungan searah antara pembiayaan konsumtif perbankan syariah dengan pertumbuhan ekonomi, semakin besar perbankan syariah menyalurkan pembiayaan konsumtif maka Pertumbuhan Ekonomi di Indonesia akan mengalami peningkatan.

\section{Uji Hipotesis (Parsial)}

Dalam penelitian ini pengujian hipotesis dilakukan berdasarkan nilai probabilitas, yaitu dengan membandingkan nilai probabilitas $\mathrm{p}$ dengan nilai signifikansi $\alpha$. Jika nilai probailitas $\mathrm{p}$ lebih kecil dari nilai signifikansi a yang ditentukan maka hipotesis (Ho) ditolak atau hipotesis alternatif ( $\mathrm{Ha}$ ) diterima dan sebaliknya jika nilai probailitas $\mathrm{p}$ lebih besar dari nilai signifikansi a yang dipilih maka hipotesis $(\mathrm{Ho})$ diterima atau hipotesis alternatif $(\mathrm{Ha})$ ditolak. Dalam penelitian ini uji hipotesis dua sisi dengan taraf signifikasi sebesar 5\%.

\section{a. Uji hipotesis Pembiayaan Produktif}

Dari tabel 4 dapat dilihat nilai t-statistik sebesar 13,117 dengan nilai probabilitas $\mathrm{p}$ sebesar 0,000 . Hal ini berarti nilai probabilitas $\mathrm{p}$ lebih kecil dari 0,05 yang menunjukkan hasil uji ini menolak Ho dan menerima Ha. Dari hasil uji hipotesis ini disimpulkan bahwa secara parsial variabel Pembiayaan Produktif perbankan syariah berpengaruh signifikan terhadap Pertumbuhan Ekonomi. Sedangkan berdasarkan persamaan regesi terlihat bahwa koefesien untuk variabel ini bernilai positif, sehingga dapat diartikan bahwa pengaruh yang diberikan oleh variabel Pembiayaan 
Produktif perbankan syariah terhadap Pertumbuhan Ekonomi adalah positif. Kondisi ini mengandung arti bahwa semakin besar perbankan syariah menyalurkan pembiayaan produktif maka dapat meningkatkan Pertumbuhan Ekonomi di Indonesia.

\section{b. Uji hipotesis Pembiayaan Konsumtif}

Dari tabel 4 dapat dilihat nilai t-statistik sebesar 0,112 dengan nilai probabilitas $\mathrm{p}$ sebesar 0,000 . Hal ini berarti nilai probabilitas p lebih besar dari 0,05 yang menunjukkan hasil uji ini menerima Ho dan menolak Ha. Dari hasil uji hipotesis ini disimpulkan bahwa secara parsial variabel pembiayaan konsumtif perbankan syariah tidak berpengaruh signifikan terhadap Pertumbuhan Ekonomi di Indonesia.

\section{Uji F (Simultan)}

Untuk melihat pengaruh variabel-variabel independen: Pembiayaan Produktif dan Pembiayaan Konsumtif perbankan syariah secara simultan terhadap variabel dependen Pertumbuhan Ekonomi di Indonesia dalam penelitian ini menggunakan bantuan software Eviews 4.1. Dari tabel 4 dapat terlihat nilai F-statistik sebesar 265,470 dengan nilai probabilitas p (F-statistik) sebesar 0,000. Hal ini berarti nilai probabilitas $\mathrm{p}$ lebih kecil dari 0,05 yang menunjukkan hasil uji ini menolak Ho dan menerima Ha. Dari hasil uji F ini disimpulkan bahwa variabel Pembiayaan Produktif dan Pembiayaan Konsumtif perbankan syariah secara simultan berpengaruh signifikan terhadap Pertumbuhan Ekonomi di Indonesia.

\section{Koefisien Determinasi $\left(R^{2}\right)$}

Untuk melihat sumbangsih variabel-variabel independen: Pembiayaan Produktif dan Pembiayaan Konsumtif perbankan syariah terhadap variasi variabel dependen Pertumbuhan Ekonomi dalam penelitian ini menggunakan bantuan software Eviews 4.1. Dari tabel 4 dapat dilihat nilai koefisien determinasi $\left(R^{2}\right)$ sebesar 0,913 yang menujukkan bahwa semua variabel independen (Pembiayaan Produktif dan Pembiayaan Konsumtif perbankan syariah) mampu menjelaskan variasi Pertumbuhan Ekonomi di Indonesia sebesar 
$91,3 \%$. Sedangkan sisanya sebesar $8,7 \%$ dijelaskan oleh variabel lain yang tidak dimasukkan dalam model penelitian ini.

\section{G.Pembahasan}

\section{Pengaruh Pembiayaan Produktif Terhadap Pertumbuhan}

\section{Ekonomi}

Hipotesis pertama dalam penelitian ini adalah untuk menguji pengaruh Pembiayaan produktif perbankan syariah terhadap Pertumbuhan ekonomi di Indonesia periode 2013-2017. Untuk menguji hipotesis pertama dalam penelitian ini menggunakan analisis regresi berganda yang menghasilkan indikasi penerimaan hipotesis. Hal ini dibuktikan dengan pembiayaan produktif memiliki nilai signifikan sebesar 0,000 $<0,05$, sehingga Ho ditolak dan Ha diterima. Artinya, Pembiayaan produktif perbankan syariah secara parsial berpengaruh signifikan terhadap Pertumbuhan ekonomi di Indonesia periode 2013-2017. Selain itu, berdasarkan nilai koefisien regresi sebesar 2,708 artinya ketika pembiayaan produktif perbankan syariah mengalami peningkatan sebesar $1 \%$ maka akan meningkatkan pertumbuhan ekonomi di Indonesia sebesar 2,708 atau $270,8 \%$ dengan asumsi variabel lain konstan. Koefisien bernilai positif artinya terjadi hubungan searah antara pembiayaan produktif perbankan syariah dengan pertumbuhan ekonomi, semakin banyak perbankan syariah menyalurkan pembiayaan produktif maka semakin dapat meningkatkan pertumbuhan ekonomi di Indonesia.

\section{Pengaruh Pembiayaan Konsumtif Terhadap Pertumbuhan Ekonomi}

Hipotesis kedua dalam penelitian ini adalah untuk menguji pengaruh Pembiayaan konsumtif perbankan syariah terhadap Pertumbuhan ekonomi di Indonesia periode 2013-2017. Untuk menguji hipotesis kedua dalam penelitian ini menggunakan analisis regresi berganda yang menghasilkan indikasi penolakan hipotesis. Hal ini dibuktikan dengan pembiayaan konsumtif perbankan syariah memiliki nilai signifikan sebesar 0,902 > 0,05, sehingga Ho diterima dan Ha ditolak. Artinya, Pembiayaan konsumtif perbankan syariah secara parsial tidak berpengaruh 
signifikan terhadap Pertumbuhan ekonomi di Indonesia periode 2013-2017. Selain itu, berdasarkan nilai koefisien regresi sebesar 0,043 artinya ketika pembiayaan konsumtif perbankan syariah mengalami peningkatan sebesar $1 \%$ maka akan meningkatkan pertumbuhan ekonomi di Indonesia sebesar 0,043 atau 4,3\% dengan asumsi variabel lain konstan. Koefisien bernilai positif artinya terjadi hubungan searah antara pembiayaan konsumtif perbankan syariah dengan pertumbuhan ekonomi, semakin banyak perbankan syariah menyalurkan pembiayaan konsumtif maka semakin dapat meningkatkan pertumbuhan ekonomi di Indonesia.

\section{Pengaruh Pembiayaan Produktif dan Konsumtif Terhadap Pertumbuhan Ekonomi}

Hipotesis ketiga dalam penelitian ini adalah untuk menguji pengaruh Pembiayaan produktif dan pembiayaan konsumtif perbankan syariah secara simultan terhadap Pertumbuhan ekonomi di Indonesia periode 2013-2017. Untuk menguji hipotesis ketiga dalam penelitian ini menggunakan analisis regresi berganda yang menghasilkan indikasi penerimaan hipotesis. Hal ini dibuktikan nilai signifikan uji $\mathrm{F}$ sebesar $0,000<0,05$, sehingga Ho ditolak dan Ha diterima. Artinya, Pembiayaan produktif dan konsumtif perbankan syariah secara simultan berpengaruh signifikan terhadap Pertumbuhan ekonomi di Indonesia. Selain itu, nilai koefesien determinasi $\left(R^{2}\right)$ sebesar 0,913 yang menunjukkan besarnya kemampuan Pembiayaan produktif dan pembiayaan konsumtif perbankan syariah dalam menjelaskan variasi pertumbuhan ekonomi di Indonesia sebesar 0,913 atau 91,3\%. Sedangkan sisanya sebesar $8,7 \%$ dijelaskan oleh variabel lain yang tidak dimasukkan dalam model penelitian ini.

\section{H.Simpulan}

Berdasarkan analisis dan pembahasan dapat disimpulkan hasil penelitian ini sebagai berikut: 1) Pembiayaan produktif perbankan syariah secara parsial berpengaruh signifikan terhadap Pertumbuhan ekonomi di Indonesia periode 20132017; 2) Pembiayaan konsumtif perbankan syariah secara parsial tidak berpengaruh signifikan terhadap Pertumbuhan ekonomi 
Pengaruh Pembiayaan Produktif...

di Indonesia periode 2013-2017; 3) Pembiayaan produktif dan konsumtif perbankan syariah secara simultan berpengaruh signifikan terhadap Pertumbuhan ekonomi di Indonesia dengan besarnya pengaruh sebesar $91,3 \%$. Sedangkan sisanya sebesar 8,7\% dijelaskan oleh variabel lain yang tidak dimasukkan dalam model penelitian ini. 


\section{DAFTAR PUSTAKA}

Anthony, Enoma, 2010. Agricultural Credit and Economic Growth in Nigeria: An Emperical Analysis, Business and Economics Journal, BEJ-14.

Badan Pusat Statistik, 2017. Indikator Ekonomi, Buletin Statistik Bulanan Agustus 2017, www.bps.go.id, diunduh pada tanggal 10 November 2017, pkl 16.18.

Bank Indonesia, 2014. Outlook Perbankan Syariah 2014, www.bi.go. id, diunduh pada tanggal 6 Februari 2014, pkl 14.42

Case, Karl E. dan Ray C. Fair, 2006. Prinsip-prinsip Ekonomi, Edisi Kedelapan, Jilid I, Jakarta: Penerbit Erlangga.

Chapra, M. Umer, 2001. The Future of Economic An Islamic Perpective (Landscape Baru Perekonomian Masa Depan). Jakarta: SEBI.

Departemen Pengembangan Pengawasan dan Manajemen Krisis Divisi Analisis Profil Industri Otoritas Jasa Keuangan (OJK), 2015. Potensi Pertumbuhan Ekonomi Ditinjau Dari Penyaluran Kredit Perbankan Kepada Sektor Prioritas, Laporan Penelitian, Jakarta: Otoritas Jasa Keuangan (OJK).

Farouk, Peri Umar dan Khotibul Umam, 2009. Mekanisme Pembentukan Bank Umum Syariah Alternatif: Akuisisi dan Konversi Bank Umum Konvensional Serta Pemisahan (Spinoff) Unit Usaha Syariah, Newsletter, No.72, Maret.

Fithriyah, Zulfita dan Nazaruddin Malik, 2014. Pengaruh Kredit Perbankan Terhadap Pertumbuhan Industri Manufaktur Dalam Menunjang Pertumbuhan Ekonomi Indonesia, Jurnal Ekonomi Pembangunan.

Judiseno, Rimsky K. 2002. Sistem Moneter dan Perbankan di Indonesia, Jakarta: PT. Gramedia Pustaka.

Kara, Muslimin H. 2005. Bank Syariah di Indonesia: Analisis Kebijakan Pemerintah Indonesia Terhadap Perbankan Syariah, Yogyakarta: UII Press. 
Levine, Ross and Sara Zervos, Stock Markets, 1998. Banks, and Economic Growth, The American Economic Review, Vol. 88, No. 3, Juni.

Mankiw, N. Gregory, dkk. 2012. Pengantar Ekonomi Makro, Jakarta: Salemba Empat.

Muhammad, 2002. Kebijakan Moneter dan Fiskal Dalam Ekonomi Islam, Jakarta: Salemba Empat.

Nain, Ahmad Shukri Mohd. dan Rosman Md. Yusoff, 2003. Konsep, Teori, Dimensi \& Isu Pembangunan, Malaysia: Universiti Tekhnologi Malaysia.

Otoritas Jasa Keuangan, Statistik Perbankan Syariah September 2014, www.ojk.go.id, diunduh pada tanggal 7 Desember 2014, pkl. 17.30

Otoritas Jasa Keuangan, Statistik Perbankan Syariah April 2013-Juni 2017, www.ojk.go.id, diunduh pada tanggal 10 November 2017, pkl 16.37

Rosser JR, J. Barkley dan Marina V. Rosser, 2004. Comparative Economcs In A Transforming World Economy, Second Edition, Cambridge, Massachussetts: MIT Press.

Suyatno, Thomas, dkk, 2007. Dasar-dasar Perkreditan. Edisi Empat. Jakarta: PT. Gramedia Pustaka.

Warde, Ibrahim, 2009. Islamic Finance: Keuangan Islam Dalam Perekonomian Global, (terj) Andriyadi Ramli, Yogyakarta: Pustaka Pelajar. 
Anton Sudrajat dan Amirus Sodiq 